\title{
Will a Collectivistic Culture protect your Intellectual Property? Effect of Individualism on Intellectual Property Protection
}

\author{
Tian Zengrui ${ }^{1}$, Guillermo A. Buitrago ${ }^{1}$, Shoirahon Odilova ${ }^{1}$ \\ ${ }^{1}$ Glorious Sun Faculty of Management, Donghua University, China \\ Correspondence: Guillermo A. Buitrago, Glorious Sun Faculty of Management, Donghua University, China.
}

Received: August 18, 2017

Accepted: October 7, $2017 \quad$ Online Published: October 13, 2017

doi:10.5539/ibr.v10n11p111

URL: https://doi.org/10.5539/ibr.v10n11p111

\begin{abstract}
This study is intended to explore the effect of individualism on intellectual property rights protection. Using data from 92 countries, we found out that individualism index has positive and significant effect on IPR protection. More specifically, a 10-point increase in individualism index is associated with 0.4-point increase in IPR index. Moreover, individualism alone seems to explain nearly $45 \%$ of cross-national variation in IPR index. The mentioned significant effect remains robust even after considering the role of economic development, democracy, ethnic diversity, economic freedom and legal heritage.
\end{abstract}

Keywords: individualism, intellectual property rights protection, Latin America

\section{Introduction}

According to The Software Alliance - BSA (2009 p. 8) the commercial value of unlicensed software used in China scored $\$ 7.6$ billion — $\$ 900$ million more than 2008; Moreover, 'in 2009, the worldwide value of unlicensed software hit $\$ 51.4$ billion. (BSA, 2009 p. 9). Therefore, understanding which tools can contribute to reduce the illegal use of software becomes a paramount research objective. Nill and Shultz (2009) assert that intellectual property rights (IPR) protection is instrumental to reducing software piracy rates across developed and developing countries. Indeed, Figure 1 suggests that IPR protection remains very heterogeneous across developed and de veloping countries. For example, while USA scored 7.7, Ukraine only got 3.9 points in the IPR protection index. Moreover, research evidence suggests that IPR protection is an important antecedent of Foreign Direct Investment FDI, technological development (Yi \& Naghavi, 2017) and trade (Auriol et al., 2015). For example, Delgado et al. (2013), using data from 158 countries between 1993 and 2009, found out that implementation of Trade Intellectual Property Agreements TRIPS had sizeable effect on trade of knowledge intensive goods. Naturally, exploring antecedents of IPR protection has numerous implications for society. Chiang (2004) explores causes of IPR protection using a large set of macroeconomic and industry specific data. The author found that patent fillings are predicted by the quality of legal institutions such as corruption levels. Das et al (2014) further shows, using data from 68 countries, reports that 'a country's economic status and regulatory status emerge as the primary factors affecting music piracy' (p.6). Furthermore, Park (2002) concluded that economic freedom and IPR protection are positively correlated across countries. In addition, economic development and trade openness are also controlled in the regression model. Odilova and Gu (2017) tested the hypothesis that culture, measured by cognitive capital, and democracy are related to IPR protection. Their study reports that the effect of cognitive skills is partially mediated by political institutions. In addition, they also show that culture explains more than $20 \%$ of cross-country variations in IPR protection.

In this study, we contribute to the existent literature by exploring the link between cultural factors and IPR protection. In particular, we test the hypothesis that individualism dimension of culture is a significant predictor of IPR protection across developing and developed countries. Related literature shows that indi vidualism is an essential ingredient of socio-economic development. For example, Gorodnichenko and Roland (2011) concluded that individualistic societies motivate personal success, thus, foster innovative activities. On national level, innovation spurs economic growth and foster development. Nikolaev et al. (2017), using pathogen prevalence index as an instrument for individualism index, tested the hypothesis that individualism is inversely related to income inequality. Their findings suggest that 'societies with more individualistic values have significantly lower net income inequality'. The results are robust even after controlling for a number of confounding factors such as economic development, legal origins, religion, human capital, other cultural values, economic institutions, and 
geographical controls (p. 30). Jha and Panda (2017) showed that individualism is a robust antecedent of corruption, even after controlling for democracy, religion, education and economic development. They also show that genetic distance and infectious diseases are significant predictors of individualism at the first stage. Drawing on this rich set of studies, is possible to conjecture that individualistic societies should be associated with stronger IPR protection. Our results showed that a 10-point increase in individualism index is associated with 0.4 -point increase in IPR index. Moreover, individualism alone seems to explain nearly $45 \%$ of cross-national variation in IPR index.

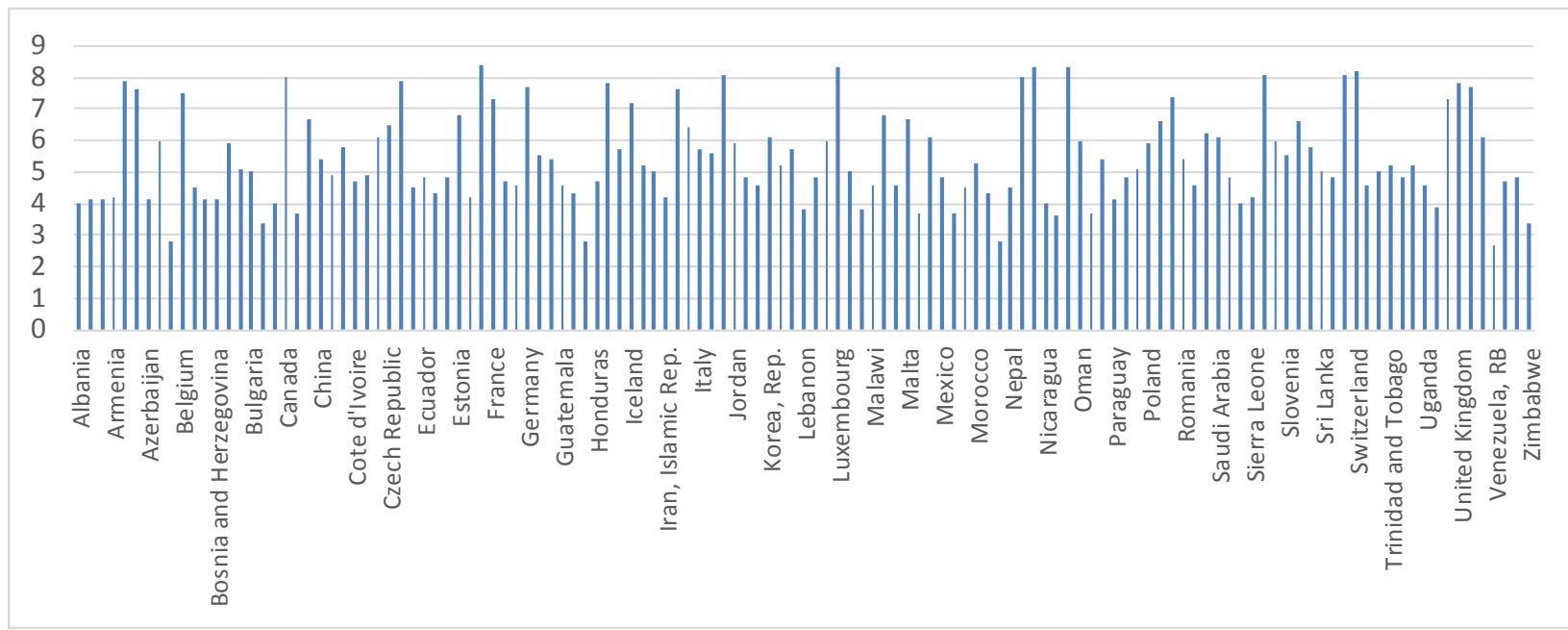

Figure 1. IPR protection index

Source: Property Rights Alliance

\section{Data}

\subsection{Dependent Variable}

Our first dependent variable is the International Property Rights (IPR) Index, the leading research output from Property Rights Alliance. The IPRI scores the underlining institutions of a strong property rights regime: the legal and political environment, physical property rights, and intellectual property rights. It is the world's only index entirely dedicated to the measurement of intellectual and physical property rights (http://internationalpropertyrightsindex.org/about).

As suggested by IPRI (2017)

The following are the three core components of the IPRI:

\section{Legal and Political Environment, LP}

\section{Physical Property Rights, PPR}

3. Intellectual Property Rights, IPR

The Legal and Political Environment (LP) component provides an insight into the strength of governance institutions of a country, the respect for the 'rules of the game' among citizens; consequently, the measures used for the LP are broad in scope. This component has a significant impact in the development and protection of physical and intellectual property rights.

The other two components of the index - Physical and Intellectual Property Rights (PPR and IPR) - reflect two forms of property rights, both of which are crucial to the economic development of a country. The items included in these two categories account for both de jure rights and de facto outcomes for the countries considered.

The overall grading scale of the IPRI ranges from [0 - 10], where 10 is the highest value for a property rights system and 0 is the lowest value (i.e. most negative) for a property rights system within a country. In our sample IPR index ranges from 2.7 in Venezuela to 8.4 in Finland.

Our second dependent variable is Intellectual property protection (IPP) index. IPP index is derived from opinion survey outcomes indicating a country's protection of intellectual property; thus, it is a predominant aspect of the IPR component. Expert participants in each country were asked to rate their nation's IP protection, scoring it from "weak and not enforced" (1) to "strong and enforced." (7). The data for this variable come from the Global Competitiveness Index from The World Economic Forum's 2015-2016. 


\subsection{Individualism}

In this study, we rely on individualism index created by Hofstede (2001) as an indicator of individualism/collectivism across societies. The first edition of Hofstede (2001)'s I/C index was estimated using data from the surveys of IBM employees in forty nations. As asserted by Jha and Panda (2017 p. 5) '[the goal of the project was to estimate the] importance an employee assigns to different work goals such as challenges at work place (sense of personal accomplishment), desirable area to live, an opportunity for high earning, cooperation, opportunities for training, fringe benefits, recognition, physical working conditions, freedom of approach to adapt to the job, employment security, opportunity for advancement, relationship with the manager, opportunity to use skill and ability at work place, and personal time'. The final $\mathrm{I} / \mathrm{C}$ index ranges from 0 (collectivistic) to 100 (individualistic) societies.

\subsection{Control Variables}

Considering that IPR protection is not explained solely by culture, as proxied by indi vidualism index, we added a vector of control variables in our empirical exercise. We included, GDP per capita as a proxy for economic development from World Bank. We also control for democracy index from Freedom House and economic freedom from heritage foundation as proxies for quality of institutions. Finally, we also control for ethnic diversity index and binary variable for countries with UK legal origins, as a measure of legal heritage. Descriptive statistics and data sources are presented in Table 1. The correlation matrix is presented in Table 2.

\subsection{Model}

To test the effect of individualism on IPR protection we estimated the following econometric model:

$$
I P R_{i}=\alpha+\beta I N D I V I D U A L I S M_{i}+X \lambda+\varepsilon_{i}
$$

Where IPR is one of our dependent variables in ith country, INDIVIDUALISM is an indi vidualism index, $\mathrm{X}$ is a vector of control variables and $\mathrm{e}$ is an error term, satisfying normality assumptions.

Table 1. Descriptive statistics

\begin{tabular}{|c|c|c|c|c|c|c|c|c|c|}
\hline Variable & \multicolumn{5}{|l|}{ Description } & Mean & $\begin{array}{l}\text { Std. } \\
\text { Dev. }\end{array}$ & Min & Max \\
\hline IPR index & \multirow{2}{*}{\multicolumn{5}{|c|}{$\begin{array}{l}\text { International Property Rights (IPR) Index from Property Rights Aliance } \\
\text { Intellectual property protection (IPP) index from World Economic } \\
\text { Forum }\end{array}$}} & 5.43 & 1.44 & 2.7 & 8.4 \\
\hline IPP index & & & & & & 4.06 & 1.03 & 1.68 & 6.31 \\
\hline Individua lism & \multicolumn{5}{|c|}{ Individualism Index from Hofstede (2001) } & 39.17 & 22.07 & 6 & 91 \\
\hline $\begin{array}{l}\text { GDP per } \\
\text { capita }\end{array}$ & \multicolumn{5}{|c|}{ GDP per capita, at 000' PPP from World Bank } & 17.78 & 20.61 & 0.64 & $\begin{array}{r}132 . \\
97\end{array}$ \\
\hline $\begin{array}{l}\text { Economic } \\
\text { freedom }\end{array}$ & \multicolumn{5}{|c|}{ Economic Freedom index from Heritage foundation } & 60.70 & 10.34 & 29.6 & 89.6 \\
\hline Democracy & \multicolumn{5}{|c|}{ Democracy index from Freedom House } & 4.66 & 1.98 & 1 & 7 \\
\hline $\begin{array}{l}\text { Ethnic } \\
\text { diversity }\end{array}$ & \multicolumn{5}{|c|}{ Ethnic Diversity index from Alesina et al. (2003) } & 0.44 & 0.26 & 0 & 0.93 \\
\hline $\begin{array}{ll}\text { UK common } & \text { D } \\
\text { law } & \text { f }\end{array}$ & \multicolumn{5}{|c|}{$\begin{array}{l}\text { Dummy variable for countries with UK common law, and zero otherwise } \\
\text { from Ashraf and Galor (2013) }\end{array}$} & 0.34 & 0.47 & 0 & 1 \\
\hline \multicolumn{10}{|c|}{ Table 2. Correlation matrix } \\
\hline & I & II & III & IV & $\mathrm{V}$ & VI & \multicolumn{2}{|c|}{ VII } & VIII \\
\hline \multicolumn{10}{|c|}{1} \\
\hline \multirow{2}{*}{$\begin{array}{l}\text { IPP index } \\
\text { Individualism }\end{array}$} & 0.9574 & 1 & & & & & & & \\
\hline & 0.7077 & 0.6667 & 1 & & & & & & \\
\hline GDP per capita & 0.769 & 0.7187 & 0.5217 & 1 & & & & & \\
\hline Economic Freedom & 0.8255 & 0.7758 & 0.5508 & 0.6359 & 1 & & & & \\
\hline Democracy & 0.5781 & 0.5074 & 0.5615 & 0.3082 & 0.6079 & 1 & & & \\
\hline Ethnic diversity & -0.3796 & -0.323 & -0.3475 & -0.3166 & -0.3229 & -0.3205 & & 1 & \\
\hline UK common law & 0.0436 & 0.1168 & 0.0443 & -0.037 & 0.0713 & -0.1675 & 0.35 & & 1 \\
\hline
\end{tabular}

\section{Results}

In column 1, we estimated a bivariate statistical model where we regress IPR index on individualism index only. This regression suggests that individualistic societies are associated with stronger enforcement of IPR protection. For example, a 10-points increase in individualism index was associated with 0.4-point increase in IPR index. Moreover, individualism alone seems to explain nearly $45 \%$ of cross-national variation in IPR index.

In column 2, we included GDP per capita. For example, Shoirova (2016) showed that culture and IPR protection is correlated with economic development both in low- and high-income countries. Moreover, Odilova and Xiaomin (2016) further showed that IPR protection is correlated with other growth determinants such as FDI. On 
the other hand, other scholars showed that individualism is significantly correlated with economic development (Ball, 2001). Therefore, it is important to control for the level of economic development. The results suggest that economic development is a significant predictor of IPR protection. In particular, a 10,000 USD increase in GDP per capita is associated with 0.4 point increase in IPR index. Individualism retains its significance, althought it has quantitatively decreased. This implies economic development captures some of the effect of individualism on IPR protection.

Next, we applied control for the economic freedom index in column 3. Economic freedom may serve as a good proxy for the quality of business environment in a country, thus may predict IPR protection. Our results suggest that economic freedom index has positive and significant effect on IPR protection. Moreover, individualism index remains positive and statistically significant.

In column 4, we incorporated democracy index. While the estimates for individualism, GDP per capita and economic freedom were positive and significant, democracy does not seem to be an important antecedent of IPR protection in our sample. In columns 5 and 6 , we included ethnic diversity and a binary variable for countries with UK common law. Both of these variables are insignificant in our regression. However, individualism was significant across all regression specifications. Therefore, the results in Table 3 suggested that individualism is a robust determinant of IPR index.

Table 3. Individualism and IPR index

\begin{tabular}{|c|c|c|c|c|c|c|}
\hline & (1) & (2) & (3) & (4) & (5) & (6) \\
\hline \multirow{2}{*}{ Individualism } & $0.0435 * * *$ & $0.0253 * * *$ & $0.0179 * * *$ & $0.0160 * * *$ & $0.0158^{* * * *}$ & $0.0150 * * *$ \\
\hline & $(0.0051)$ & $(0.0042)$ & $(0.0034)$ & $(0.0038)$ & $(0.0039)$ & $(0.0040)$ \\
\hline \multirow[t]{2}{*}{ GDP per capita } & & $0.0435 * * *$ & $0.0249 * * *$ & $0.0262 * * *$ & $0.0259 * * *$ & $0.0266 * * *$ \\
\hline & & $(0.0051)$ & $(0.0045)$ & $(0.0047)$ & $(0.0048)$ & $(0.0048)$ \\
\hline \multirow{2}{*}{ Economic freedom } & & & $0.0681 * * *$ & $0.0625 * * *$ & $0.0624 * * *$ & $0.0595 * * *$ \\
\hline & & & $(0.0087)$ & (0.0104) & $(0.0105)$ & (0.0109) \\
\hline \multirow[t]{2}{*}{ Democracy index } & & & & 0.0631 & 0.0593 & 0.0752 \\
\hline & & & & $(0.0537)$ & $(0.0544)$ & $(0.0571)$ \\
\hline \multirow[t]{2}{*}{ Ethnic diversity } & & & & & -0.1581 & -0.2719 \\
\hline & & & & & $(0.2887)$ & $(0.3136)$ \\
\hline \multirow[t]{2}{*}{ UK common law } & & & & & & 0.1486 \\
\hline & & & & & & $(0.1594)$ \\
\hline \multirow[t]{2}{*}{ cons } & 4.0180 *** & $3.7385 * * *$ & 0.0700 & 0.1303 & 0.2408 & 0.3563 \\
\hline & $(0.2304)$ & $(0.1705)$ & $(0.4860)$ & $(0.5103)$ & $(0.5508)$ & $(0.5650)$ \\
\hline$N$ & 89 & 88 & 88 & 87 & 87 & 87 \\
\hline adj. $R^{2}$ & 0.4530 & 0.7112 & 0.8312 & 0.8279 & 0.8264 & 0.8261 \\
\hline
\end{tabular}

Standard errors in parentheses

$* \mathrm{p}<0.1, * * \mathrm{p}<0.05, * * * \mathrm{p}<0.01$

In Table 4, we re-estimated our baseline results using IPP index as a dependent variable. The relationship between individualism and IPR protection is positive and significant at $1 \%$ level across all models. After controlling for GDP per capita, economic freedom, democracy, ethnic diversity and legal origins, a 20-point increase in individualism index was associated with 0.2-point increase in IPP index (column 6).

Table 4. Individualism and IPP index

\begin{tabular}{|c|c|c|c|c|c|c|}
\hline & (1) & $(2)$ & (3) & (4) & $(5)$ & $(6)$ \\
\hline \multirow[t]{2}{*}{ Individualism } & $0.0303 * * *$ & $0.0178 * * *$ & $0.0128 * * *$ & $0.0133 * * *$ & $0.0134 * * *$ & $0.0116 * * *$ \\
\hline & $(0.0039)$ & $(0.0036)$ & $(0.0032)$ & $(0.0035)$ & $(0.0036)$ & $(0.0036)$ \\
\hline \multirow[t]{2}{*}{ GDP per capita } & & $0.0300 * * *$ & $0.0169 * * *$ & $0.0167 * * *$ & $0.0169 * * *$ & $0.0183 * * *$ \\
\hline & & $(0.0042)$ & $(0.0042)$ & $(0.0044)$ & $(0.0045)$ & $(0.0045)$ \\
\hline \multirow[t]{2}{*}{ Economic freedom } & & & $0.0480 * * *$ & $0.0476^{* * *}$ & 0.0476 *** & $0.0421 * * *$ \\
\hline & & & $(0.0081)$ & $(0.0099)$ & (0.0099) & $(0.0102)$ \\
\hline \multirow[t]{2}{*}{ Democracy } & & & & -0.0050 & -0.0029 & 0.0284 \\
\hline & & & & $(0.0497)$ & $(0.0504)$ & $(0.0520)$ \\
\hline Ethnic diversity & & & & & $\begin{array}{c}0.0837 \\
(0.2728)\end{array}$ & $\begin{array}{c}-0.1496 \\
(0.2929)\end{array}$ \\
\hline \multirow[t]{2}{*}{ UK common law } & & & & & & $0.2896^{*}$ \\
\hline & & & & & & $(0.1463)$ \\
\hline \multirow[t]{2}{*}{ Constant } & $3.0824 * * *$ & $2.9035 * * *$ & 0.3049 & 0.3460 & 0.2865 & 0.5066 \\
\hline & $(0.1769)$ & $(0.1426)$ & $(0.4559)$ & $(0.4828)$ & $(0.5229)$ & $(0.5259)$ \\
\hline$N$ & 92 & 91 & 91 & 90 & 90 & 90 \\
\hline adj. $R^{2}$ & 0.3938 & 0.6177 & 0.7241 & 0.7131 & 0.7100 & 0.7198 \\
\hline
\end{tabular}

Standard errors in parentheses $* \mathrm{p}<0.1, * * \mathrm{p}<0.05, * * * \mathrm{p}<0.01$ 
In Table 5, we focused on one region of the world, namely Latin America. We regressed our dependent variables on individualism, dummy variable for Latin America countries and their interaction term. The results, reported in columns 1 and 2, suggested that the effect of individualism on IPR protection is marginally weaker in this region. One explanation may be that this region is associated with overall collectivistic cultures. On the other hand, the dummy variable for Latin America countries may capture unobserved characteristic such as colonization or endowment in natural resources such as oil, forest or copper. These resources hinder economic development and deteriorate legal institutions, so called resource curse phenomena.

Table 5. The effects in Latin America

\begin{tabular}{|c|c|c|}
\hline & (1) & (2) \\
\hline & IPR index & IPP index \\
\hline \multirow[t]{2}{*}{ Individualism } & $0.0451 * * *$ & $0.0314 * * *$ \\
\hline & $(0.0054)$ & $(0.0042)$ \\
\hline \multirow[t]{2}{*}{ Latin America } & 0.7903 & 0.5917 \\
\hline & $(0.5591)$ & $(0.4826)$ \\
\hline \multirow[t]{2}{*}{ Individualism * Latin America } & $-0.0369^{*}$ & $-0.0290 *$ \\
\hline & $(0.0197)$ & $(0.0163)$ \\
\hline \multirow[t]{2}{*}{ Constant } & $3.9532 * * *$ & $3.0440 * * *$ \\
\hline & $(0.2914)$ & $(0.2134)$ \\
\hline$N$ & 89 & 92 \\
\hline adj. $R^{2}$ & 0.4551 & 0.3967 \\
\hline
\end{tabular}

Standard errors in parentheses $* \mathrm{p}<0.1, * * \mathrm{p}<0.05, * * * \mathrm{p}<0.01$

\section{Conclusion}

Software piracy and violation of copyright rules are still present across developed and developing countries. Several papers have shown that economic development, democratization, reduction of corruption and stronger legal environments can contribute to solve to this problem. Meanwhile, in the other hand, a separate strand of literature has shown that cultural dimension seem to be important antecedents of socio-economic development.

In this study, we have explored the role of one aspect of cultural values, namely indi vidualism, in improving IPR protection across developed and developing countries. Our results suggested that a 10-point increase in individualism index is associated with 0.4-point increase in IPR index. Moreover, individualism alone seems to explain nearly $45 \%$ of cross-national variation in IPR index. These results indicate that apart from fostering economic development and strengthening legal institutions to reduce copyright violations, it is important to take into account the role of culture in modeling IPR protection using global data.

\section{References}

Alesina, A., Devleeschauwer, A., Easterly, W., Kurlat, S., \& Wacziarg, R. (2003). Fractionalization. Journal of Economic growth, 8(2), 155-194. https://doi.org/10.1023/A:1024471506938

Ashraf, Q., \& Galor, O. (2013). The "Out of Africa" hypothesis, human genetic diversity, and comparative economic development. The American Economic Review, 103(1), 1-46. https://doi.org/10.1257/aer.103.1.1

Auriol, E., Biancini, S., \& Paillacar, R. (2015). Intellectual Property Rights Protection and Trade.

Ball, R. (2001). Indi vidualism, collectivism, and economic development. The Annals of the American Academy of Political and Social Science, 573(1), 57-84. https://doi.org/10.1177/000271620157300104

Chiang, E. P. (2004). Determinants of cross-border intellectual property rights enforcement: The role of trade sanctions. Southern Economic Journal, 424-440. https://doi.org/10.2307/4135300

Das, S., Mukhopadhyay, A., \& Bagchi, K. K. (2014). National-level determinants of global music piracy and online music sales: an exploratory study. Journal of Global Information Technology Management, 17(1), 6-25. https://doi.org/10.1080/1097198X.2014.910988

Delgado, M., Kyle, M., \& McGahan, A. M. (2013). Intellectual property protection and the geography of trade. The Journal of Industrial Economics, 61(3), 733-762. https://doi.org/10.1111/joie.12027

Gorodnichenko, Y., \& Roland, G. (2011). Individualism, innovation, and long-run growth. Proceedings of the National Academy of Sciences, 108(Supplement 4), 21316-21319. https://doi.org/10.1073/pnas.1101933108

Hofstede, G. (2001), Culture's Consequences: Comparing Values, Behaviors, Institutions and Organizations across Nations, 2nd edition. Sage Publications, Thousand Oaks.

Jha, C., \& Panda, B. (2017). Individualism and Corruption: A Cross - Country Analysis. Economic Papers: A journal of applied economics and policy. 
Nikolaev, B., Boudreaux, C., \& Salahodjaev, R. (2017). Are individualistic societies less equal? Evidence from the parasite stress theory of values. Journal of Economic Behavior \& Organization, 138, 30-49. https://doi.org/10.1016/j.jebo.2017.04.001

Nill, A., \& Shultz, C. J. (2009). Global software piracy: Trends and strategic considerations. Business Horizons, 52(3), 289-298. https://doi.org/10.1016/j.bushor.2009.01.007

Odilova, S. (2016). Patent protection, intelligence and economic growth: a cross-country empirical investigation. Journal of Research in Business, Economics and Management, 6(1), 798-803.

Odilova, S., \& Gu, X. (2017). Cognitive Abilities, Democracy and Intellectual Property Rights Protection. International Business Research, 10(5), 127. https://doi.org/10.5539/ibr.v10n5p127

Odilova, S., \& Xiaomin, G. (2016). Intellectual Property Rights Protection and FDI: Some Correlational Evidence. Journal of Research in Business, Economics and Management, 7(4), 1217-1221.

Park, W. G. (2002). Patent rights and economic freedom: Friend or foe? Journal of Private Enterprise, 18(2).

Yi, X., \& Naghavi, A. (2017). Intellectual property rights, FDI, and technological development. The Journal of International Trade \& Economic Development, 26(4), 410-424.

https://doi.org/10.1080/09638199.2016.1266380

\section{Copyrights}

Copyright for this article is retained by the author(s), with first publication rights granted to the journal.

This is an open-access article distributed under the terms and conditions of the Creative Commons Attribution license (http://creativecommons.org/licenses/by/4.0/). 